The Challenge of Fundamentalism 
Comparative Studies in Religion and Society

Mark Juergensmeyer, editor

1. Redemptive Encounters: Three Modern Styles in the Hindu Tradition, by Lawrence Babb

2. Saints and Virtues, edited by John Stratton Hawley

3. Utopias in Conflict: Religion and Nationalism in Modern India, by Ainslie T. Embree

4. Mama Lola: A Vodou Priestess in Brooklyn, by Karen McCarthy Brown

5. The New Cold War? Religious Nationalism Confronts the Secular State, by Mark Juergensmeyer

6. Pious Passion:The Emergence of Modern Fundamentalism in the United States and Iran, by Martin Riesebrodt, translated by Don Reneau

7. Devi: Goddesses of India, edited by John Stratton Hawley and Donna Marie Wulff

8. Absent Lord:Ascetics and Kings in a Jain Ritual Culture, by Lawrence A. Babb

9. The Challenge of Fundamentalism:Political Islam and the New World Disorder, by Bassam Tibi

10. Levelling Crowds: Ethno-nationalist Conflicts and Collective Violence in South Asia, by Stanley J. Tambiah

11. The Bridge Betrayed: Religion and Genocide in Bosnia, by Michael A. Sells 


\section{The Challenge of Fundamentalism}

Political Islam and the

New World Disorder

$-\infty-\infty$

\section{Bassam Tibi}

UNIVERSITY OF CALIFORNIA PRESS

Berkeley · Los Angeles · London 
University of California Press

Berkeley and Los Angeles, California

University of California Press, Ltd.

London, England

(C) 1998 by

The Regents of the University of California

Library of Congress Cataloging-in-Publication Data

\section{Tibi, Bassam.}

The challenge of fundamentalism : political Islam and the new world disorder / Bassam Tibi

p. $\mathrm{cm}$. - (Comparative studies in religion and society ; 9 )

Includes bibliographical references (p.) and index. ISBN 0-520-08868-9 (alk. paper)

1. Islam and politics. 2. Islamic fundamentalism. 3. Islam-2oth century. I. Title. II. Series. BP173.7.T56 1998

320.5'5'0917671-dc21 97-17138

Printed in the United States of America

987654321

The paper used in this publication meets the minimum requirements of American National Standard for Information Sciences-Permanence of Paper for Printed Library Materials, ANSI Z39.48-1984. 